\title{
Integrating Learning Technologies (Mobile Devices) into the Teaching and Learning of English Language in Higher Institutions in Nigeria
}

\author{
Christiana Ijeoma Ajaps \\ Department of English and General Studies \\ Federal College Of Education (Technical), Nigeria
}

\begin{abstract}
Modern technologies have the capacity for adaption in teaching/learning and research at different levels of education. ICT provides a medium through which a learner can choose what, where and how to learn in a globalized world. Digital leaning is already making a lot of impact in the western world. However, ICT potentialities is yet to be fully explored in Nigeria due to some misconceptions. Teachers, scholars and researchers in Nigeria have bemoaned the perceived negative influence of GSM phones (an offshoot of ICT) on teaching and learning in our schools. They have therefore identified and passionately discussed a number of these negative influences and their effects on our education system. The focus of this paper, however, is to make a case for the incorporation and use of mobile devices in the classrooms in higher institutions despite the identified negative effects. The paper outlines and discusses some of the advantages of these technological inventions to education especially, the teaching and learning of the English language, as seen by scholars in other parts of the world. From this author's classroom experience too, GSM has been found to aid the teaching and learning process. Since each learner has peculiar cognitive and personality traits, no one teaching method will be suitable for all students. The use of mobile devices provides avenues for students to select materials and techniques from various sources from the internet. Hence, ICT provides modern techniques applied to diversify teaching/learning styles and meet with individual needs. The paper, therefore, submits that teachers and educators should incorporate the use of GSM phones into the English language teaching and learning process in higher institutions so as to achieve maximum teaching-learning results. While enjoining them to continually educate their students on its salutary use and the need to play down on the negative aspect of its use. Based on the conclusion above, some recommendations were made, among which are - that English language teachers should be encouraged to become ICT compliance; government should made sufficient funds available to ensure that ICT equipment are provided for schools, as well as subsidize internet data charges.
\end{abstract}

\section{Introduction}

The concept of Information and Communication Technology (ICT) is complex in that it has not yielded itself to any definite, concise and precise definition. This might be as a result of its evergrowing qualities from one socio-cultural and political environment to another. Anderson [2] defines ICT as the physical structure of network of computer base systems for purposes of organizing, processing, presenting, storing, retrieving and simplifying information when needed and in the form needed. In a similar vein, Nwana [12], defined ICT as the science of information processing which deals with the use of computers and other electronic devices to collect, process, store, retrieve and transmit or disseminate information to any part of the world. The above definition may be broadened to mean that any computer-based tool, equipment or gadget which can be used to collect and process information, support and manage the information needs of an individual, organization, corporation and institution comes under the concept of ICT. While Thierer [17], avers that ICT in education is a vehicle through which a learner can decide what he learns, where he learns and how he learns because we are now in the era of globalization where the free flow of information via satellite and internet sway in global information dissemination of knowledge. Perhaps, it is in line with the above that the National Policy on Education [9] recognizes ICT as a product of technological change and as an innovation in education.

The Global System of Mobile communication (GSM) is a subset of ICT. It is widely used all over the world today as the most effective tool for communication. It is handy and common among youths and adults alike. The GSM has a number of features and devices like games, short message services or text message, multi-media, music, Bluetooth, web access and so on. New software information as desired by the user may also be stored onto the GSM phone for personal use. The result of the above is that a phone user may be engaged by this device for a whole day. Specifically, in Nigeria, virtually all the working class and non-working class as well as literate and illiterate use GSM [8]. The numerous devices in the cell phone and their 
utilitarian values endear the GSM to a large number of people in Nigeria. While some use it to make or receive calls, others use it to send text messages, multimedia messages, to browse the internet and for both audio and video recordings. Others use it as notebooks to store information and as phone camera. Today, even secondary school students carry GSM phones all about to perform quite many of these functions. As a result, the belief is very strong among teachers and educational researchers that GSM has been affecting the learning outcome of students in schools, especially with respect to the orthography of the English language.

\section{GSM and the Acquisition of the English Language in Nigeria}

Researchers, educators and stakeholders in the education enterprise in Nigeria have over the years bemoaned the negative influence of GSM phones on the teaching and learning process in schools, especially with respect to English language acquisition. Many have, therefore, called for its ban among students in educational institutions; a call we now know is very impossible at least in higher institutions where the system believes that students are adults and should be allowed a degree of freedom. Some students who come to classes with phones are busy chatting, making calls, sending/receiving text messages and playing games on their phones during lectures. We note also that some students in higher institutions are in the habit of taking snapshots of their colleagues, and even of some of their lecturers who may not even be aware during class hours. This impedes learning as it implies lack of concentration. The problem of lack of concentration is oven less dangerous than the effect of the use of GSM on the orthography of the English language. These days, many students copy unacceptable linguistic forms: wrong spellings and improper abbreviations into their schoolwork. The call for the ban on the use of GSM phones among students in schools is therefore understandable given the above background. Specifically, Onadeko [13] examined the extent to which some Nigerian undergraduates transfer chat room lingo into their academic writings. The study found out that internet lingo is creeping into undergraduates' academic writings and warned that the trend portents a serious danger for the evolution of Nigerian Standard English. Also, Faleke and Ibrahim [8] spoke in a similar vein. They investigated the use of GSM communication through the SMS device to see how the various styles of writings adopted by Nigerians have been transferred into the formal writing in the essay questions. Data was the selected 2016 WASSCE essays of students and these researchers observed the occurrences of GSM writing indicators at the morphophonemic, orthographic and expression levels which largely negatively affect the performance of students in the examinations. The study concluded that the occurrences of these features in formal essay writing may eventually retard the standard of English usage in Nigeria.

Chiluwa [4] was rather mild in his description of the 'Nigerianness' he observed in the text messages. He described his observation as 'new linguistic style' [4] that shows that the language has a new form of orthography. Alabi [1] was rather very blunt as she referred to the perceived problems of the GSM communication as 'method in madness'. According to Egya [6] "there is a great injury being inflicted on this English Language with the explosion of the telecommunication in Nigeria today". The paper posits that the art of letter writing has virtually collapsed, courtesy of the GSM phones since young people write letters only if they have to apply for jobs and, that even then the letters are often riddled with common errors. Of great worry to the researchers is the unconscious intrusion of shorthand into the students' official writing. Generally, these scholars and many others like them are worried and concerned about the negative effects of the GSM on the students' acquisition of the English Language. Therefore, quite many teachers and educational researchers in Nigeria believe that cell phones have no place in the educational process. More often than not, educators generally tend to view new technologies as a great distraction from the learning process. They often quickly posit that banning the devices in educational institutions is the answer without thinking of educating the students as an option. Despite the apathy expressed by these teachers and researchers towards the incorporation and use of cell phones in schools however, our teeming students are already using their phones to learn what they want to know. Some of what they learn on their phones are what these educators including myself frown upon. But since we cannot separate them from these gadgets, we suggest that the best we can do is to consciously invite their phones into the classroom situation so that they begin to use the cell phones for worthwhile academic tasks.

\subsection{Mobile Devices (GSM Phones) and Students in the English Language Classrooms}

The stark reality in Nigeria today is that students, especially undergraduates are addicted to mobile devices (GSM phones, tablets and Ipads). Mobile devices now have important place in young people's lives. Mobiles phones are the most popular among the technological devices available in this age. Prensky [14] maintains that mobile phones outnumber personal computers. Young people, especially undergraduates, can hardly do without it. 
Perhaps, it is in recognition of the above - stated reality and its great importance to education that many foreign research works seem to be positive towards the use of GSM phones as tools of instruction in classrooms. Bar, Tews and Robling [3] investigated classroom interaction based on the mobile phone owned by most students. The study discussed a prototype for mobile phones-based interaction. The study which was based on the assumption that both students and educators can benefit from software support in very large lectures posited that the use of GSM is a cost-effective and widely usable solution to over-populated classroom. Similarly, VanHilst and Griss [18] propose the use of cell phones and PDAs as teaching tools and target platforms for teaching undergraduate students. The study believes that the devices are common among students, less expensive and support load -and -go course materials that students can access anytime, anywhere. Furthermore, the study believes that with network connectivity, students can use their phones in collaborative group work. So [16] study focuses on the development of a SMS-based teaching and learning system. The study reveals the underlying technology of using the GSM modems to build the SMS-based teaching and learning system while claiming that the system is capable of supporting administrative, teaching and learning activities via the technology. Activities like brainstorming, voting and assessment activates supported by the system are used as illustrations.

Expressing a contrary opinion, Prensky [14] lamented the trends in American schools thus: 'For as U. S. educators are busy banning cell phones in schools, millions of students in China and Japan, the Philippines, and Germany are using their mobile phones (respectively) to learn English, to study Math, health and spelling; and to access live and archived university lectures. The above succinctly sets out side-by-side the relevance of GSM phones in institutions of learning. Further, it also explains in unambiguous terms some of the benefits the students and tutors in these other nations are deriving from the use of the devices as part of classroom instruction.

Mcneal and Hooft [10] are of the view that 'using real life resources for teaching and learning in the classroom can make education more meaningful and relevant to our students'. Researching on ways of adopting cell phones in ESL/EFL teaching and learning environment, Cui and Wang [5] focus on the application of cell phones in teaching and learning of English language to Chinese learners of English. The study specifically calls that 'Educational departments, schools and teachers should advocate and promote the integration of cell phones in educational field'. Reinders [15] discusses twenty practical ways by which mobile phones can support English language learning in and out of the classroom. Believing that students are already intimately familiar with the cell phones and that teachers who use them have benefitted greatly, the study also discusses some problems in its use and suggests ways of bypassing such problems.

Based on our discussions so far, we wish to state that while we see some reasons in the position of those are against the use of GSM phones in schools, we propose its acceptability in higher institutions of learning under a controlled classroom situation. This proposal hinges on VanHilst and Griss [18] that the devices are convenient, cool and as such has a great appeal in the curriculum. Again, our numerous students in institutions of higher learning are 'addicted' to the devices. What then are its appeals or relevance in the teaching and learning of English language in the Nigerian situation?

\subsection{The Relevance of Mobile Devices in English Language Teaching and Learning}

From this researcher's experience as a teacher in a Nigerian higher institution of learning, we have realized that it is now greatly difficult for undergraduates to come to classes and lectures with their dictionaries. To these students, coming to lectures with a copy of the Oxford Advanced Learners Dictionary of the English Language or any such big dictionaries is a great problem because it is heavy to carry about. The only alternative that seems pleasant then is to let such students download such software on their phones. It is easier and more convenient for students to press a few buttons on their handy phones to get to their dictionaries, look up various meanings of lexical items, their correct spellings and pronunciations and so on than it is to carry about a dictionary, a book of close to two thousand pages. The use of the electronic dictionary through the GSM phones further aids classroom interaction and immediate feedback, since there are always many students who may not like to interact verbally in classes. Waite, Jackson and Diwan [19] are of the view that interaction and feedback as essential components of lectures can improve the success of learning. Therefore, lecturers and students should strive to achieve meaningful interactions via the mobile devices because many students feel rather comfortable interacting with their cell phones and then, sharing the information they get with their course mates.

Generally, the teaching of English language in Nigeria is aimed at imparting the practical language skills of listening, speaking, reading and writing to enable the recipient use the language effectively, competently and intelligently. According to Faleke and Ibrahim [8] the goals of language skills of learners are such that they can function better in their studies, their work and in their interactions with people from other cultures. ICT via the mobile 
devices can comfortably be utilized in the teaching of reading, continuous writing, speech, listening and vocabulary building. Research findings [8], [13], [20] show that the use of ICT via mobile devices in English language teaching/learning is quite effective. With the help of ICT facilities, a skilled teacher can download interesting documentaries from the internet for motivating students' interest in reading. Stories, histories, pictures and other school activities are all motivational resources which could be harnessed at will. For instance, Alabi [1] study used a downloaded material to motivate reading. His students were made to watch educational documentaries depicting students who excelled in examination and became as a result of constant and effective reading. Discussions followed these expositions with supervised reading. This way students were motivated in the four areas of attention, relevance, confidence and satisfaction, leading to extensive reading. This is quite impressive considering that reading skill is a very important giving that we now live in an information age, a reading world, a world where survival without reading is becoming increasingly dicey and where the timely possession of that vital information gives the holder a competitive edge over his/her peers. Also, new vocabularies can be taught by using a slide show of images downloaded from a ready-made source from the internet through mobile devices. The images can be used to prompt students for answers. We can learn courses in languages, Literature, writing, debates and public speaking just as we can learn courses in Physics, Chemistry and Economics on many of the cell phones we carry about. Quite many phones today have the capabilities to bring to students' lessons in their chosen subject areas, especially with respect to English language lessons, given the importance of the language in the world today. Personally, I have discovered that on my mobile phone, it is very simple for me to scroll to Life tools, to Education and to Learn English. Many students can enjoy English lessons through this medium even when they are not in their classrooms. I have therefore introduced many of my students to this simple opportunity to learn the language on the go. GSM phones have also been found very useful in classroom situations where the students feel the need to record lectures during lecture hours. What students often do during lectures is partly to listen to their lecturer as she/he delivers the lectures and also go on to write down necessary points in their notebooks. The task of listening or paying attention to lectures and writing down important points in their notebooks at the same time may often be too demanding on students. Students, in the process, often miss important discussions while busy writing down some points. Smart and wiling students may now choose the option of scrolling their phones to the voice recorder option and select. Of course, they also need to deactivate their ringing tone so that incoming calls will not distract the attention of the class. This strategy is particularly rewarding for students in a class that is not very large, in which case learners are reasonably not sitting far from their lecturer. The method saves the learners from writing anything during lecturers and allows them to concentrate fully on the delivery. Further, students can later listen to the text of the lecture as many times as they like and anywhere. We also believe that such recordings may be transferred to other students who might have missed the lectures and are willing to benefit from the classes.

Mobile devices/Cell phones have also been found very useful among students for chat room talks. Students feel more at home, more comfortable and freer when they only have to express themselves through online chats. Sullivan (2002) as quoted in Onadeko [13] asserted that online chat creates a more comfortable atmosphere for its users. When a group of students agree among themselves to have an online group discussion, they may be far away from one another and still enjoy the benefit of having a group discussion on a particular lecture or topic, say History of English Language in Nigeria. In this type of arrangement, students who are considered very timid in class feel less inhibited and are able to express themselves freely. The online group discussion will normally improve students' academic performances in the long run as they would have gained more from the experiences of course mates, while learning in the comfort of their chosen environments. It will also gradually enhance the public expressive ability of the timid students. McKenna, Green and Gleason [11] found that the lonely and socially anxious people were able to express themselves and develop close friendship on the internet than in the 'real world'. This is because when a group of students engage in a chat room discussion of academic or schoolwork, they enjoy the benefit of online chat and still save the time they should have spent to engage in unrewarding online chats.

Closely linked to the above discussion are the web services which the GSM phones afford. Students can easily browse with their phones than with their laptops to get desired information because of its mobility and its handy nature. They can quickly browse to read and download specific information as it relates to their academic work. Once I gave an assignment to my class on one of Christopher Okigbo's poems. I was thrilled when, the next day, the students were discussing and analyzing the poem. When I voiced my surprise, one of them told me with enthusiasm, 'Sir, Okigbo's works are on the net! In fact, internet browsing has turned cell phones into mobile electronic libraries. The students can now have their thesaurus, dictionaries and encyclopedia with them anywhere 
they go. They can instantly access websites and can gain access to research such as e-books and instructional materials. These materials on their phones can be read as many times as they like without the burden of carrying heavy books. Audio books too can be downloaded as listening materials for students' enjoyments and these can be played back on any phone with good audio capacities. Course contents, course notes and scholars' perceptions on particular subject matter can be accessed by undergraduates to help them forge ahead in their class work. Some students, as a result of this opportunity may have read ahead of the class. Web services have also made the task of the lecturer easier as he may give individual assignments which demand that students browse the net to study internet materials. The lecturer only needs to generally discuss such topics in class since the students have had background knowledge of the lesson from the net. Students also savour the joy of discovering new information by themselves which makes learning more interesting and permanent.

The game applications on the mobile devices can also be very useful to students as it relaxes them and develops in them mental alertness as well as critical thinking abilities. Cui and Wang [5] 'maintain that playing games offer people a good way to relax while enjoying benefits such as developing problemsolving and critical thinking skills.' Today, a number of instructional games are available on cell phones. They include games on building vocabularies, memorization of spellings of words and fill-in thegap questions and answers. Many others can still be downloaded by willing students. Thus, students who engage in such instructional games have the advantage of learning while still playing and relaxing. Likewise, cell phone camera can aid learning and make learning very interesting and enjoyable when systematically introduced into the curriculum. This facility can be very useful for visual reporting. We consider a tutor whose task is to teach his students topics in report writing, narrative or descriptive essay. After feeding them with the initial theoretical format of such essay or report writing, he gives assignment to the students to video-record any of the following scenes: a market scene, family dinner, graduation ceremony, scene of a fight or transaction in a supermarket. This will normally stimulate students' interests as they have the chance to change to play with their phones as part of the learning process. Arriving in class with their video recordings, the teacher now tells them to write down their reports. Certainly, a descriptive, narrative or report written by students when the pictures and the events are staring at them will be more detailed, more real, easy and better accomplished. This is because narrations and descriptions become alive and more accomplished when they still remain vivid in the sight of the narrator.
Again, Freedman [7], outlines some benefits of learning technologies (ICT) to include:

i. Providing both the resources and the pedagogical frameworks for enabling students to become effective independent learners;

ii. Placing learners on equal footing (giving similar hardware and software and curriculum activities, even severely disabled students can achieve the same degree of success as anyone else).

iii. iii. Increasing the intelligence, creativity and spirit of teamwork in the learning environment.

Williamson [20] notes that a lot of supplementary materials exist in the internet for English language teaching and learning.

\subsection{Challenges of Using Mobile Devices by Students in Higher Institutions in Nigeria}

Irrespective of the fact that the use of mobile devices (ICT) has brought immense benefits to humanity, it has also some problems. These include: 1. The services (data) are costly for learners considering the average state of a Nigerian;

2. Lack of secrecy for it gives free access to uncensored information about students;

3 . It is time consuming especially when surfing the net;

4. They are lots of sites and information that distract students, therefore it must be supervised by teachers/parents;

5. Irregular power supply to charge the mobile devices is another major drawback; and

6. Non-ICT compliance by teachers and learners. And so on.

\section{Conclusion}

This paper which began with the discussion of the unfavourable attitudes of educators towards the use of mobile devices such as GSM phones in the classrooms in Nigeria, has been able to state and discuss these educators' reasons for such attitudes. While the paper attempted to see reason with this group of scholars, it held the belief that banning the devices in higher institutions of learning may be tantamount to banning the students themselves from schools, a feat which is very difficult if not impossible. Banning it in higher institutions is somehow impossible due to the fact that quite a large number of these students are already pathologically addicted to these devices. Teachers and educators should, therefore, find a way systematically to incorporate its use into the teaching-learning process. The paper then discussed some perceived benefits of cell phones to students in the English language classes and called on teachers and educators to invite 
the phones into the classrooms for worthwhile academic tasks. The paper advises that the use of mobile devices during lectures should be controlled by lecturers and teachers and, students should be continually educated on how best to handle the devices for maximum academic output. To this end, conscious and deliberate effort should be made to encourage the use of mobile devices by students in Nigeria, especially those in higher institutions of learning.

\section{Recommendations}

For the promotion of use of ICT in the teaching/learning of English Language in Nigerian Higher Institutions of Learning, the following recommendations were made:

1. It is imperative for English language teachers not to discourage their students from use of mobile devices, rather they should consciously introduce them to computer lingoes. But, should however, point out to them to focus more on the beneficial use of ICT for academic purposes.

2. Higher education needs to be ICT based hence, the need for government to allocate enough funds to education for provision of ICT equipment.

3. Government should also intensify efforts towards the improvement of electricity power supply in the country.

4. Employers of labour should provide ICT training for English language teachers for effective delivery of the subject matter in higher institutions.

5. Government should encourage the use of mobile devices by students through provision of subsidy to ensure cost reduction of data usage.

\section{References}

[1] Alabi, V. A. (2018) "Problems of an Emergent written Language of the Global System for Mobile Communication (GSM) in Nigeria." Proceedings of the 22nd Annual Conference of the Nigerian English Studies Association (NESA) Volume 2, No. 1

[2] Anderson, P (2017). Information and Communication Technology and Enhancement of Education in the 21st Century. Akure. JBS Publishing Company Ltd.

[3] Bar, H., Tews, E. \& Robling, G. (2015) "Improving Feedback and Classroom Interaction using Mobile Devices." Proceedings of the IADIS International Conference Mobile Learning. Pp. 55-62.

[4] Chiluwa, I. (2017) "The 'Nigerianness' of SMS Text Messages in English.” In Journal of the Nigerian English Studies Association (JNESA). Vol. 3, Number 1. 95-105.

[5] Cui, G. and Wang, S. (2018). Adopting cell phones in EFL teaching and learning. In Journal of Educational Technology. Development and Exchange. Vol.1, No. 1 retrieved from: www.sicet.org/journals/jetde/jetde08/paper 06.pdf retrieved on 11/12/2018.

[6] Egya, S. E. (2019). "Crippled Idiom: The English Language in Nigeria in the Twenty-First Century." A Paper Presented at the 7th ELTT Annual National Conference of Teachers and Researchers in English as a Second Language (NATRESL). Held between 6th and 9th February, 2009 at The Federal Polytechnic, Nasarawa.

[7] Freedman, T (2015. Using Mobile Devices in the Classroom. In Journal of ICT in Education. Volume 8. No. 4

[8] Faleke, V. O. \& Ibrahim, S. S. (2018). "GSM Text Messages: Impediments to English Orthography in the 21st Century." In Journal of the Nigerian English Studies Association (JNESA). Vol. 14, Number 2. 51 - 62.

[9] Federal Republic of Nigeria. (2014). National Policy on Education (4th ed). Lagos: NERDC press.

[10] McNeal, T. \& Hooft, M. (2016). "Anywhere Anytime: Using Mobile Devices for Learning." In Journal of the Research Centre for Educational Technology Volume 2 No. 2

[11] McKenna, K. Y. A. Green, A. S. \& Gleason, M. E. J. (2017). "Relationship Formation on the Internet: What is the big Attraction?" Journal of Social Issues. 58, 9-31.

[12] Nwana, S. E. (2018). "ICT and Functional Education for Adolescents in Education." In Journal of Guidance and Counselling. 1 (1), 77-84.

[13] Onadeko, T. (2017). "Chatroom Talk and Its Influence on the Acquisition of the English Language in Nigeria." In Journal of the Nigerian English Studies Association (JNESA). Vol. 14, Number 1. 60 - 70.

[14] Prensky, M. (2018). "What can You Learn from a Cell Phone?" Almost anything! Innovate (5). Retrieved from http://www.innovateonline:info/index.php?view= article\&id $=83$ on 3/4/2018.

[15] Reinders, H. (2018). "Twenty Benefits for using Mobile Devices in the English Language Classroom." In Journal of English Teaching Forum, Volume 2. No3.

[16] So, S. (2013). "The Development of an SMS-based Teaching and Learning System." In Journal of Educational Technology, Development and Exchange, 2(1), 113 - 124.

[17] Thierer, Anthony (2015) ICT in Education in a Digital World Washington Post

[18] VanHilst, M. \& Griss, M. (2016). "Cell Phones as Tools to Teach Computer Science." Second LACCEI International Latin American and Caribbean Conference for Engineering Technology. Miami, Florida.

[19] Waite, W. M. Jackson, M. H. \& Diwan, A. (2013). "The Conversational Classroom." In The 34th Annual Technical Symposium on Computer Science Education (SIGCSE). New York: ACM. 
Literacy Information and Computer Education Journal (LICEJ), Volume 11, Issue 1, March 2020

[20] Williamson, K., (2016). The Use of ICT in English Language Teaching/Learning. In The British Journal of Education Technology. 41(2). 